04

\title{
CRIME PATTERN \& PREVENTION THROUGH URBAN ENVIRONMENTAL DESIGN USING GIS
}

\author{
Rupesh Kumar Gupta \\ Assistant Professor, Dr. Bhim Rao Ambedkar College, University of Delhi, Delhi, India \\ Email: gisrs2004@gmail.com
}

How to cite this paper:

Gupta, Rupesh Kumar

(2021) Pattern \& Prevention

of Crime through Urban

Environmental Design Using

GIS, Journal of Global

Resources, Vol. 07 (02)

DOI:

10.46587/JGR.2021.v07i02.004

Received: 28 March 2021

Reviewed: 25 April 2021

Revised: 17 May 2021

Final Accepted: 25 May 2021

\section{OPEN O A C C E S S}

Freely available Online www.isdesr.org
Abstract: The current study investigates the spatial pattern of crime, with a focus on specific locations and times. Crime is not strewn throughout cities; rather, there are certain areas in cities that are relatively small but where crime occurs much more frequently than elsewhere (the socalled "hotspots"), making them highly vulnerable and predictable. This paper investigates the relationship between "hotspots" and urban environment features like as layout design and criminal attribution in relation to location. The research is based on previously published data, a small primary survey, and GPS-GIS mapping. The study discovered that faulty building design, crowded high mobility areas, isolated dark places, parks, shades, and vacant plots are the most vulnerable to crime. It has been observed that increasing surveillance and developing infrastructure such as metalled road-drains, parks, metro stations, and so on do not reduce crime but rather shift the location of crime from one location to another. The findings highlight the importance of rethinking specific aspects of urban design. This has sparked an increased interest in the study of communities and urban design.

Keywords: Mega City, Crime Mapping, Layout Design, GPS, GIS 


\section{Introduction}

Crime is a part of any societies considering that its origin. It varies from one community to another. Even within one community it doesn't occur equally in all locations and nor in the same way. This is observed that the micro environment and layout design of the places play an important role behind the crime. Crime is an activity which is against the law. The concept of crime is the straightforward definition of crime is that "crime is something that is against the law" (Rosiers \& Bittle, 2004), and defined in the dictionary as "an act punishable by law, as being forbidden by statute or injurious to the public welfare" Erdogan, 2007). Due to the complex nature of the subject of crime, its varied causes and consequences, various academic disciplines such as criminology, sociology, geography, psychology and demography study it from their own perspective. Clark and Marshall (1952) wrote: "A crime is any act or omission prohibited by public law for protecting the public and punishable by the state in a judicial proceeding in its own name". Similarly, Tappan (1960) defined that "A crime is an instrumental act or omission in violation of criminal law, committed without justification and sanctioned by the state as felony or misdemeanour". In city planning and especially in urban design, the concept of crime is based on the reality that crime occurs in a space (Gupta,2020a). Therefore, city planning designs spaces to prevent crime. The criminality fact in city planning depends on principles to design special spaces that prevent crime, thinking that the crime depends on the space. The criminality facts and its space explanation help determine the planned design space for the city planner. To create a secure urban manmade space, it is necessary to accurately consider the fact of criminality (Duzgun, 2007). As can be seen here, approaches to crime and research topics differ from discipline to discipline. Sociology studies the social reasons for crime, while psychology focuses on the individual that commits the crime. City planning, especially urban design is concerned with physical attributes of an urban space that affect the occurrence of crime.

Crime rates are not evenly distributed over geographical areas in urban settings. That is to say, incidents are not distributed randomly; rather, there are certain areas in cities that are relatively small, but where crimes occur much more frequently than elsewhere (the socalled "hotspots"), making them highly vulnerable and predictable (Goldsmith \& McGuire, 2000). This has drawn attention to the study of localities and urban design. It was Newman (1972) who first identified the relationship between specific aspects of urban design and levels of crime. In his theory "Crime Prevention through Environmental Design", he argues that urban design influences the incidence of crime and the formation of hotspots. Other authors have also claimed that urban design and environment may play a part in whether to commit a crime (Geason \& Wilson, 1989); for example, the lack of natural vigilance, poor lighting and other variables means that a small area may easily be transformed into a potential crime hotspot.

According to Crowe (2000), urban design and the proper use of the urban space may help reduce fear of crime, and even its incidence, contributing to an improvement in quality of life. Prevention requires criminal justice agencies to be proactive rather than reactive, and proactivity requires the ability to predict crime hotspots and concentrations. Prediction is rarely possible from individual events, thus there is a direct link between prevention and patterns of criminality, in the form "prevention requires proactivity requires predictability requires patterns" (Ratcliffe 2009). The importance of identifying patterns as a precursor to effective crime prevention has been identified by practitioners who recognize the inherent ability of crime mapping to identify patterns and hotspots, taking advantage of Tobler's first 
rule of geography, that "Everything is related to everything else, but near things are more related than distant things" (Tobler, 1970, Gupta, 2020b).

In conclusion, as Brantingham and Brantingham (1981) said, there are four things that have effects on the occurrence of crime. These are law, offender, target, and place. Brantingham and Brantingham (1981), claim that "without an offender, someone who breaks the law, there is no crime. Without some object, target, or victim, there is no crime. Without a place in time and space where the other three come together, there is no crime". Crime occurs when these dimensions are in concurrence. However, this paper deals with only the fourth dimension of crime, which is "place". It strives to understand crime and crime prevention according to city planning principles, especially urban design, in the context of the case study of Delhi (Gupta, 2020a). This paper is divided into 4 parts, focusing respectively on the following issues: 1 . the distribution of crimes and the identification of high-crime prone areas (hotspots); 2. the association between the hotspot of crime and the layout design of buildings, 3. developed the inventories map of crime prone area and the preventive measure through a map of that area and, 4. The ascription of offender related to different crime location.

\section{Aim and research question}

The following objectives have been planned as the basis for the investigation of the problem of this study. This study analyzes the spatial pattern of crime in different areas of Delhi and selects the most vulnerable (top ten) crime prone places for further study of its layout design and micro environment. Next, to prepare a detailed inventory map of land uses and security arrangement existing crime prone places, as well as perspective planned and designed map has been prepared for each hotspot to prevent crimes.

\section{Study Area}

National Capital Territory is spread over an area of 1483 sq. km. between $28^{0} 23^{\prime} 17^{\prime \prime} \mathrm{N}$ \&

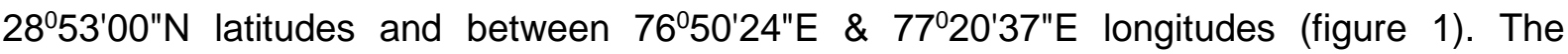
demographic changes in NCT Delhi occurred more rapidly in last hundred years and over forty-fold (1911-0.41 to 2011-18.45 million) increase in its population has been noticed, but it was not uniform during the past century. In the late twentieth century, the National Capital Territory of Delhi has grown more rapidly in terms of population (Census of India). As most scholars agree, that the exploding population growth has created insurmountable challenges including socio-economic development, protection of the environment, development of infrastructure, congestion, high density, rural-urban transformation and the burgeoning growth of slum dwellers and social security and growth of crime in the state.

\section{Data and Methodology}

For this purpose, we go through government official published data like national crime research bureau (NCRB), Delhi Police website, different document-report-policies papers, research thesis, observational data of projects, magazine, articles, and daily newspaper and Primary field information of last 10 years. Then we prepared a list of crime-prone area of Delhi. We observed that some areas where the frequency of crime is much more, so according to the frequency of crime we revised the list. For the time constraints and resource limitation, we selected the top ten (high-frequency crime area in the last 10 years) crimeprone areas from that list for further study. After that, we visited all ten most vulnerable areas and interacted with local people, municipal bodies, local police, government and private official, as well as a small shopkeeper, to know about the exact location (hotspots) of the crime and reason behind it. Then we came to know that entire area or locality is not crime 
prone, but the particular location (hotspots) of that area is crime-prone, where the crime occurred frequently in last 10 years (Figure 1). These are Anand Vihar Metro Terminal, Seemapuri Bus Stop, Gokalpuri Bus stop \& Metro station, Old Delhi Railway \& Metro Station, New Delhi Railway \& Metro Station, Sarai Kale Kha Bus Terminal \& Nizamuddin Railway Station, Kashmiri Gate Bus \& Metro Terminal, Vishwavidyalaya Metro station, Jahangirpuri Metro station and Vasant Vihar Bus stop.

Once we know about the ten major hotspot locations of crime, then we prepared a structured questionnaire and randomly interviewing 250 individuals in each crime hotspot (this means that total $10 \times 250$ questionnaire) in 2014. To bring out the effect more clearly, a separate interview of 250 people each from the same 10 hotspots undertaken in 2018 through random sample method. We tried to investigate the crime occurred in each place, surrounding environment of the hotspot, and mapping layout design of the surrounding building of hotspots. The data for the micro physical environment also collected by making inventory map of dark/isolated places, open/close parking, forest, bushy patches, crowed area and installation of surveillance devices etc. for each identified stations/stand. We prepared an inventory map in the dimensions of 500 meters from the center of all hotspot places through GPS. Geographical Information System (ESRI Arc GIS-Arc Map) and Global Poisoning System (Trimble-Juno 3B Handheld GPS) techniques have been used for mapping of micro-environment in and around the hotspot places.

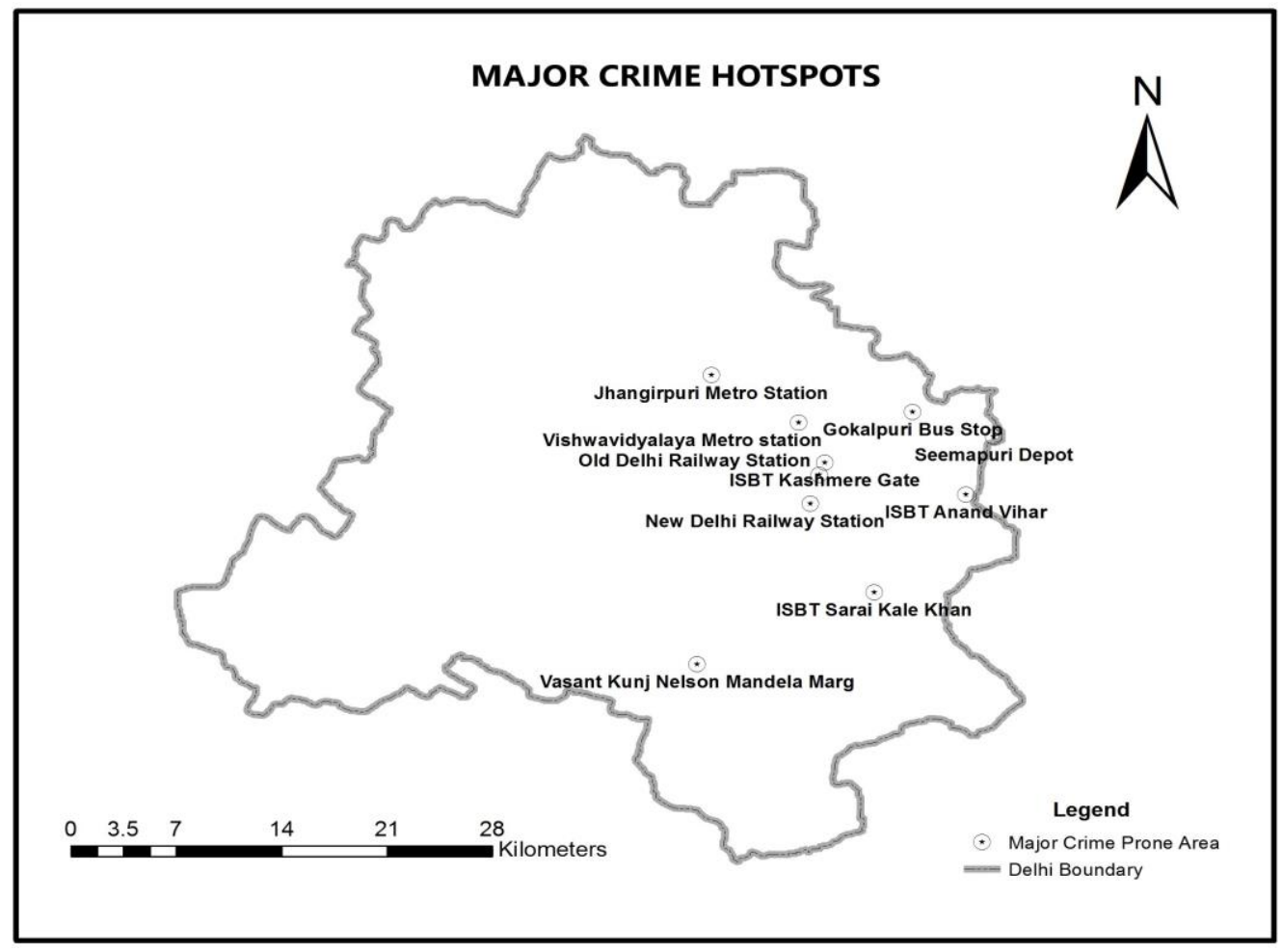

Figure 01: Major Crime Hotspots

\section{Spatial Pattern of Crime}

When we talk about crime and place, then one question emerges in the mind that is, where and why the crime has taken place and what was the supporting factor of that crime. So first let's go through these stages. The first stage is to ask where the recorded crime took place in addition, who committed the crime and why? This helps to build up a profile of the places or environments where most crime and control encounters occur alongside profiles of offenders and victims. 
A second stage is to consider how places can be altered in ways that might reduce crime. This can involve several of factors, from definitions of what makes a particular location 'crime-prone' or 'safe' to the arrangement and purpose of buildings to local beliefs or memories about a place. It can also involve several agents, from planners, developers and politicians, ones who have the power to change the spaces, to ordinary people who have the everyday task of negotiating existing spaces. A third stage is to consider how we come to know about space and crime in the first place and what we do with that knowledge. Mapping statistics has been a central methodological tool in this kind of criminological research. This raises questions about the source of the statistics and the nature of mapping technology. To plan and design a place, it is necessary to understand the land use pattern, its management, surveillance mechanism (natural and digital) and social organizational structure. With this perspective, the ascriptions of each of the selected hotspots were prepared. A brief account is as under:

a) Anand Vihar (Bus, Rail and Metro Terminal): Anand Vihar is one of the major transit places where Railway Junction, Bus Terminal, and Metro Terminal service are available, we may call it Tri Junction-where commuters interchange and move in a different direction (figure $2, \& 11$ ). This is highly crowded and because of that most of the crime occurs here. The major crimes are pick pocketing, assault, snatching and abuse. Due to Tri-junction and sharing of a border with another state (Uttar Pradesh) offenders would commit the crime and escape easily. Most of the offenders lived in Kodia Pul, Ghazipur, Hasanpur Village, Old Seemapuri, Dilshad Garden, Kalyanpuri, Seelampur, and Jhilmil area. All these areas are low income, urban slum, low literacy and poor infrastructure (table-1). There are many uncared dark areas and abandoned buildings within the terminal boundary with no proper electric lights and digital surveillance devices. Wide-open unmaintained sewers drain with small tree/bushes alongside it is running between the terminal and outer ring road (figure-2). Crowding at Outer Ring Road is a common feature during peak hours. It is a high crimeprone place where pick-pocketing and snatching are the most prevalent.

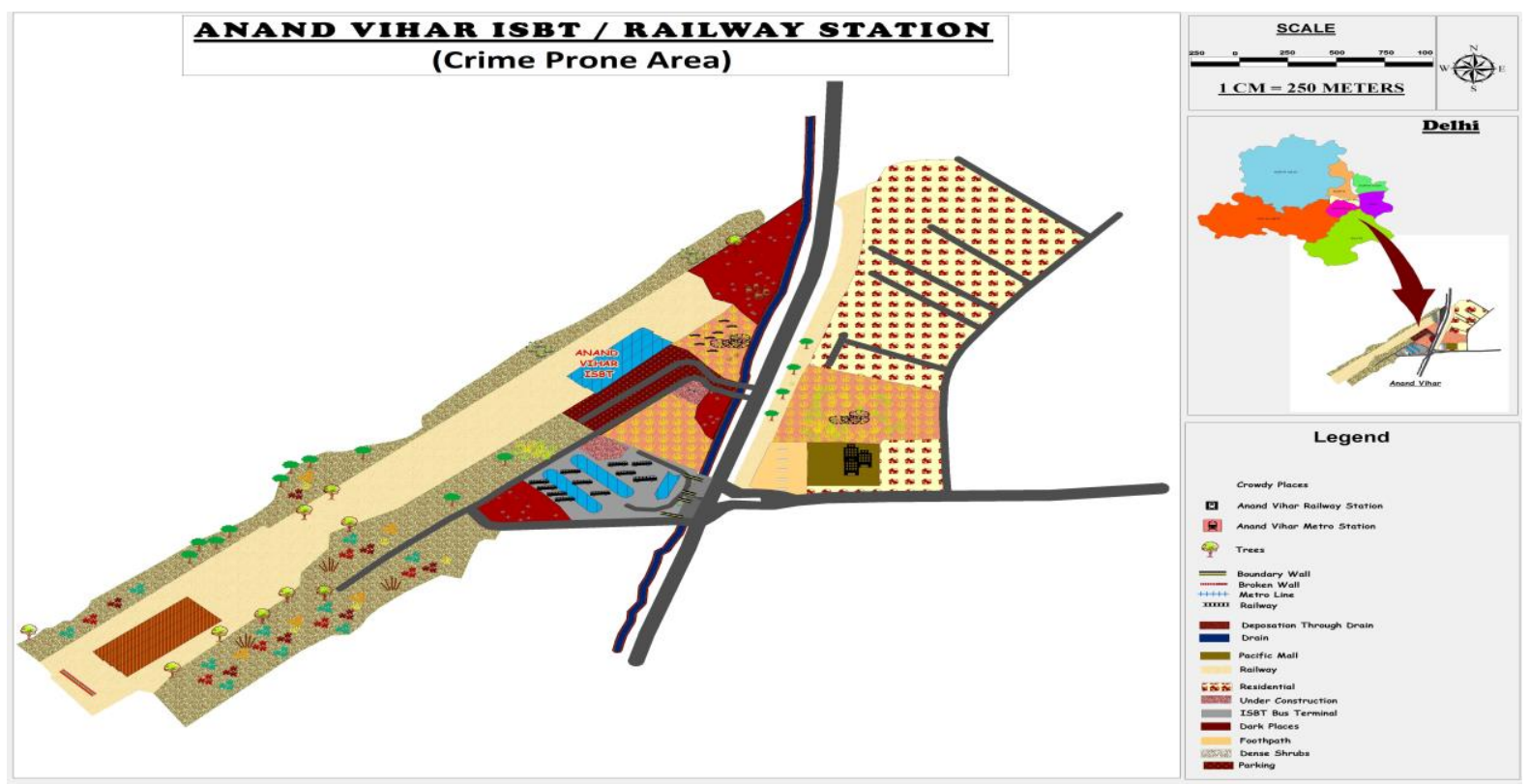

Figure 02: Anand Vihar Railway Station (Sources: Google Earth, 2018 and GPS Survey)

b) Seemapuri Bus Terminal: Another hotspot of crime is Seemapuri, near the border of Uttar Pradesh. It is also a bus terminal and urban slum makes it a high crime-prone area (figure3, \& 11). Another lacuna is poor infrastructure, low literacy rate and presence of Bangladeshi population makes it easy for offenders to escape to other states like Uttar 
Pradesh. Most of the offender lived in Sunder Nagari, Anand Vihar, Old Seemapuri, Old Seelampur, and Nand Nagri (table-1). Many unplanned Jhuggi Jhopri clusters have come up along the western side of the road. A dense economically low-class residential colony is present in the east. With the poor arrangement of lights, no surveillance devices, dark patches and crowding at the bus stop, pickpocketing and snatching incidents (53 percent) are high here. Relocation of Jhuggi Jhopri from parks, and public places and provision of CCTV Cameras, proper maintenance of encroached parks, illumination of the entire area and police surveillance are necessary to prevent/control crimes at this place (figure 3 ).

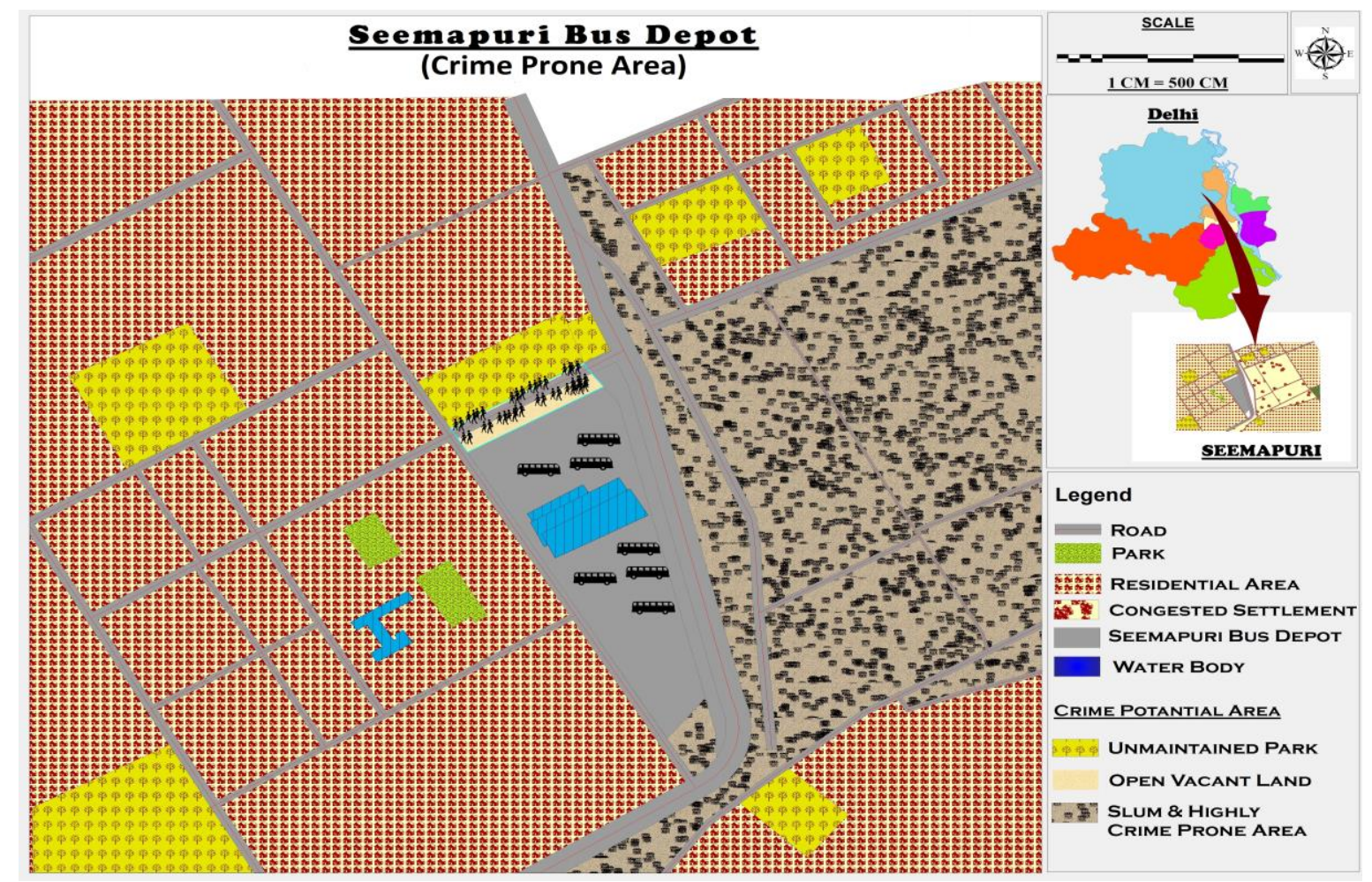

Figure 03: Seemapuri Bus Depot (Sources: Google Earth, 2018 and GPS Survey)

c) Gokalpuri Bus Stand: In the eastern part of Delhi, Gokalpuri bus stand and metro station are another prominent crime-prone transit place, covered by a low-income group alongside the long drain and near to major traffic point-Gole Chakkar, which make this place more crowded and crime-prone (figure 4, \&11). Assault, Snatching, Rape, Abuse and pick pocketing are more prominent here and most of the offenders are living in Loni Border, Seelampur, Maujpur, Nand Nagri, Rehman Building, Kardam Puri, Khajuri Khas, Jafrabad, Seemapuri, and Chitrakoot (table-1). Within $500 \mathrm{~m}$ in the south many vacant plots, unmaintained graveyards, open drains alongside the road are present. Faulty design of flyover on the round about blocks the visibility on both sides. Such features create fear of crimes, particularly in the college students and school children. This area needs proper monitoring of graveyards along with illumination, digital surveillance and creating visibility across the flyover (figure 4).

d) Vishwavidyalaya Metro Station: In the northern part of Delhi, one more important transit places and major commuters' point are Viswavidyalaya metro station, where most of the young students are present during the day and night, which makes it a favorable place of the crime (figure5 \& 11). The offenders lived in Majnu Ka Tilla, Ganda Nalla, Azadpur, Jahangirpuri etc. and involved in snatching, abuse and pick pocketing. Snatching and pick pocketing are prominent here. There are few bushy patches and vacant, unmaintained and abandoned parking area here which create a fear of crime at this place. The area along the 
Nazafgarh drain is not maintained properly, darkness at night creates fear of crime to the visitors. It needs a proper arrangement of electric lights and regular digital surveillance. Here non-serious crimes like snatching, abuse, pick pocketing, smoking and drinking are prevalent, this is as per the perception of the people (figure 5).

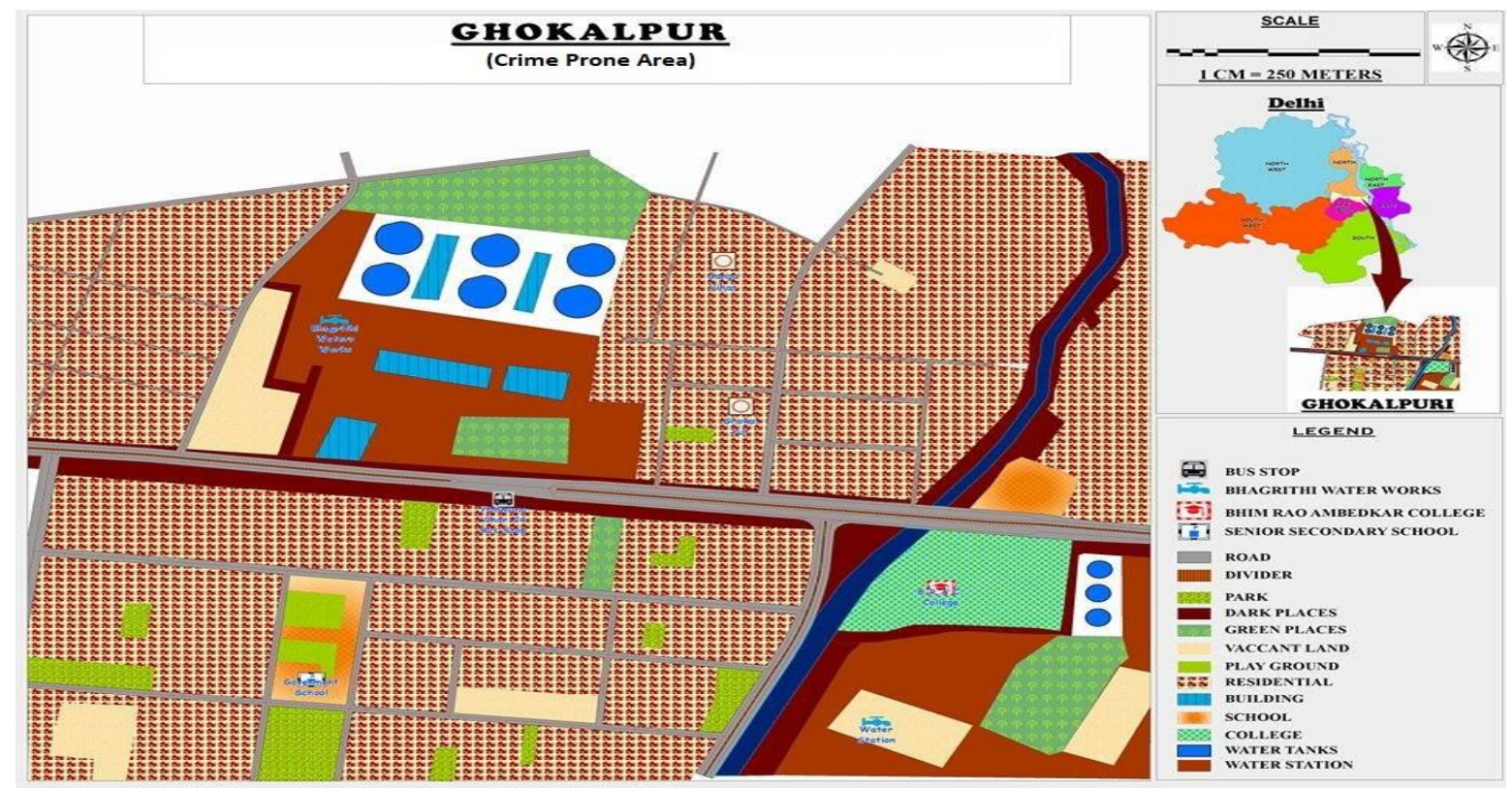

Figure 04: Ghokulpur (Sources: Google Earth, 2018 and GPS Survey)

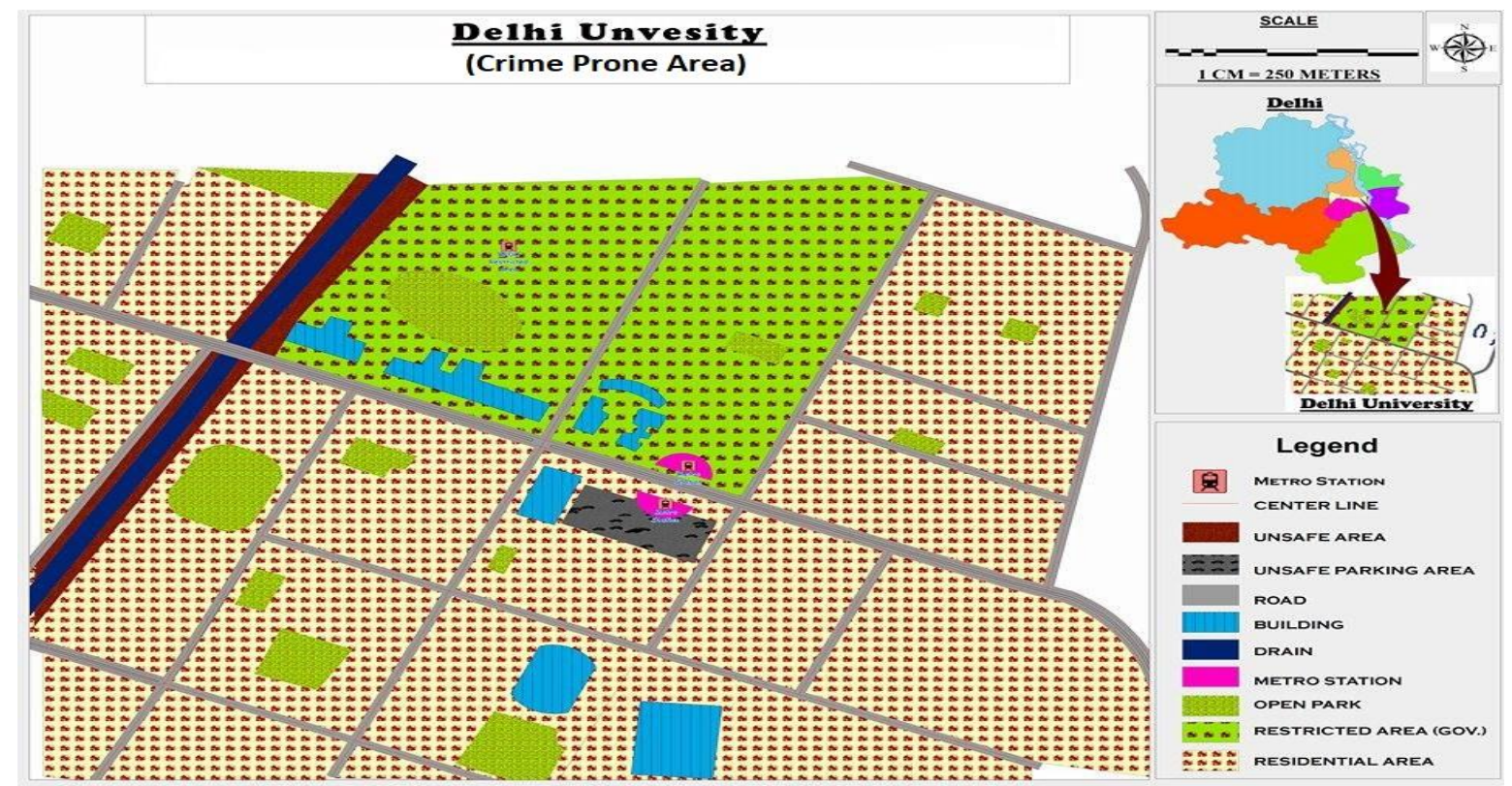

Figure 05: Delhi University Area (Sources: Google Earth, 2018 and GPS Survey)

e) Jahangirpuri Metro Station: In the northern border area, near bypass expresswayJahangirpuri is in the north part of Delhi and close to the border of Haryana near to DelhiBahadurgarh-Sonipat Expressway (figure 6, \&11). Most of the crimes that take place here issnatching, assault, abuse, pick pocketing etc. the offenders lived in Samaypur Badli, Wazirpur, Azadpur, Sunder Nagri, Old Seemapuri, Bhalswa Dairy, etc.

This place is surrounded by the economically low-class residential colony and Jhuggi Jhopri cluster in the North-east. In the south, there is a vacant plot and a major transport corridor. The unmaintained vacant plots, lonely bushy area and near Haryana makes it a 
suitable hotspot for crime. Areas under major trilateral fly-over called outer Circle Bypass require proper digital surveillance and police monitoring (figure 6).

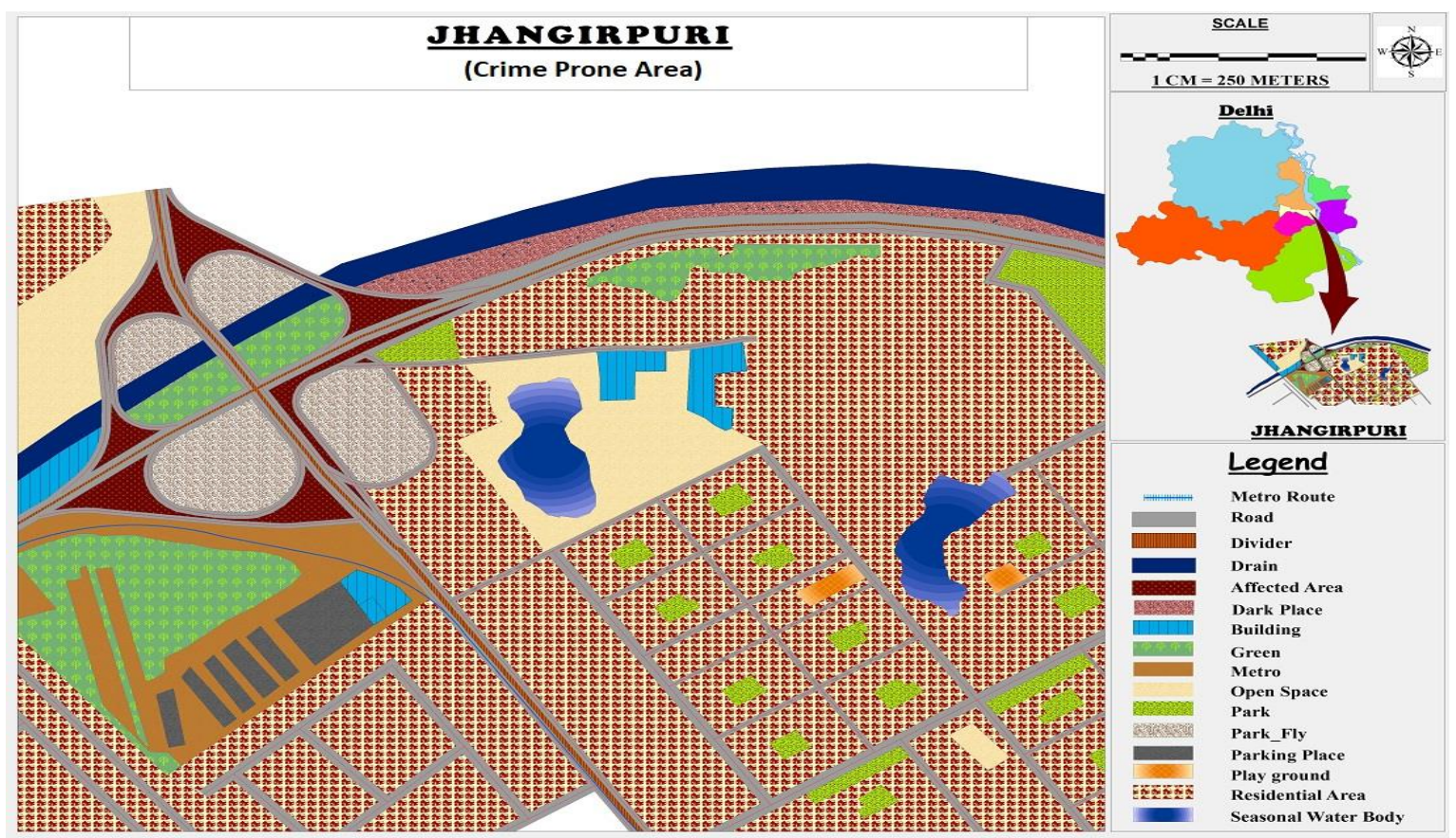

Figure 06: Jahangpuri Area (Sources: Google Earth, 2018 and GPS Survey)

f) New Delhi Railway \& Metro Station: In central Delhi, New Delhi railway \& metro station is one of the major terminals where the mobility of people is always very high during the day and night (figure 7\& 11). Most of the offenders are living in Paharganj, Anand Parbat, Pulbangash, Chandni Chowk, Seelampur and Ghaziabad, are involved in Snatching, molestation, abuse and Motor vehicle theft. In the railway junction, there is Paharganj market, an urban slum-like Multani Dhanda, Ram Nagar, Aram Bagh, and the parking area of the station are highly crime prone.

The entrance to New Delhi is from two sides; Paharganj and Ajmeri Gate. The area in front of railway station towards Paharganj is perceived to be more fear due to un-monitored crowding of the public, auto and manual rickshaw, a shelter for diversified people like Matkawala, Rail Hawker, etc. The platform is safe by the respondents but the areas along the railway line attract crime due to unmaintained and abandoned railway boogies. Therefore, areas along the railway line should be cleaned and maintained with proper illumination and installation of the CCTV cameras and proper fencing (figure 7).

g) Kashmiri Gate-ISBT/Metro Terminal: In the north of Delhi, Kashmere Gate is one of the largest Inter State Bus Terminal (ISBT) and Metro Terminal in Delhi where many commuters interchange his services and moved in a different direction (figure 8 \&11). This is a center of high mobility of people in day and night, that's the reason this is a favourable hotspot for criminal. Because of its multifaceted communication point, various crimes such as pick pocketing, abuse, and snatching have occurred here. The offender lives in Khajuri Khas, Nand Nagri, Yamuna Bazar, Seelampur, Usmanpur and Chandni Chowk (table-1). In a diameter of $500 \mathrm{~m}$ the highest crime hotspot is the places under the flyover and the parking lots. There are many dark places which create fear in public because to improper lighting and poor maintenance. It is a crowded place due to the interchange point of commuters of bus, metro and rail. The bus parking has many dark corners, which requires monitoring through a digital device with a camera. The area under 
and along the flyover should be maintained through the clearing of bushes and trees and installation of digital devices along with the high density of police patrolling in the night (figure 8).

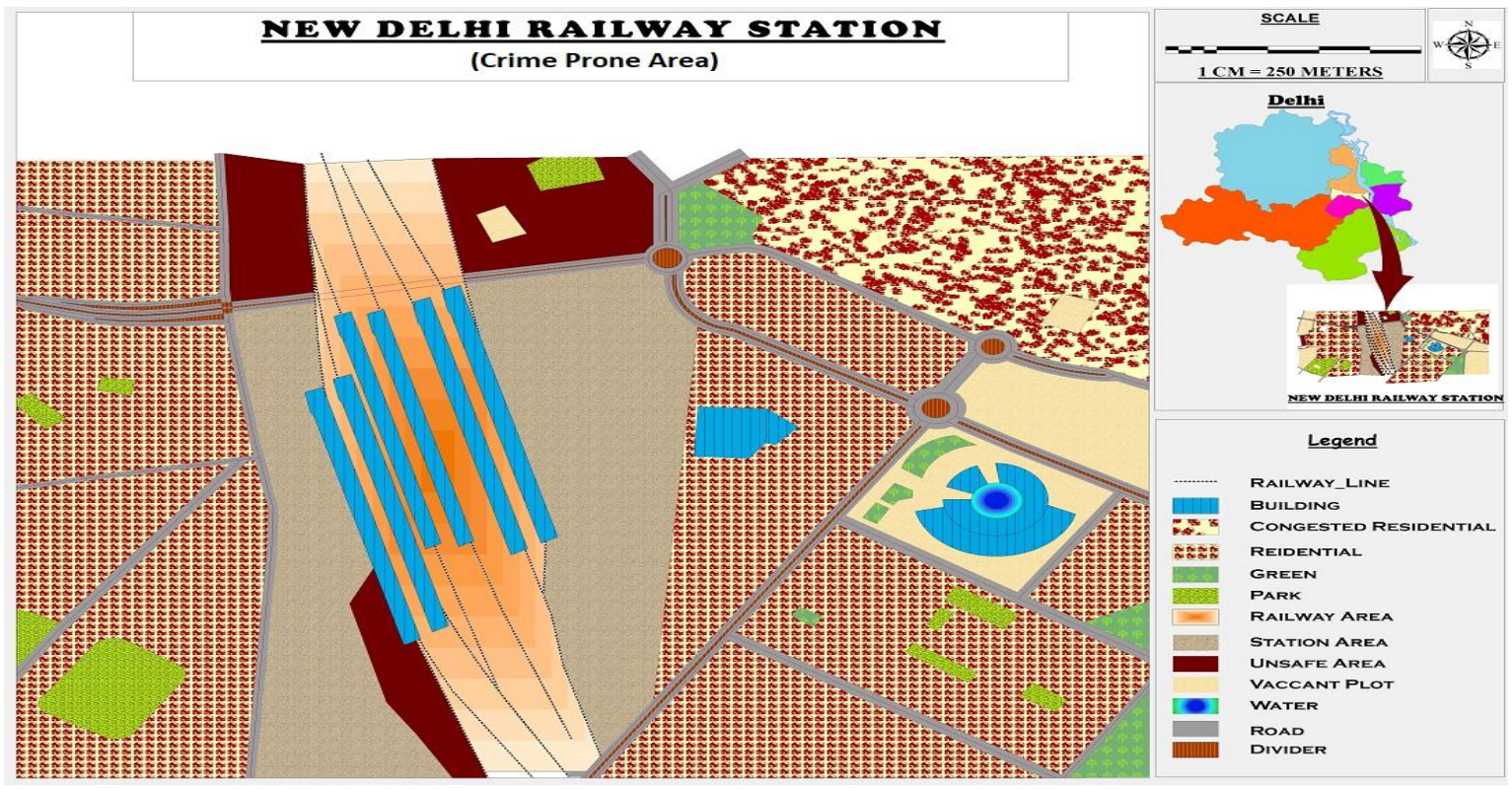

Figure 07: New Delhi Railway \& Metro Station (Sources: Google Earth, 2018 and GPS Survey)

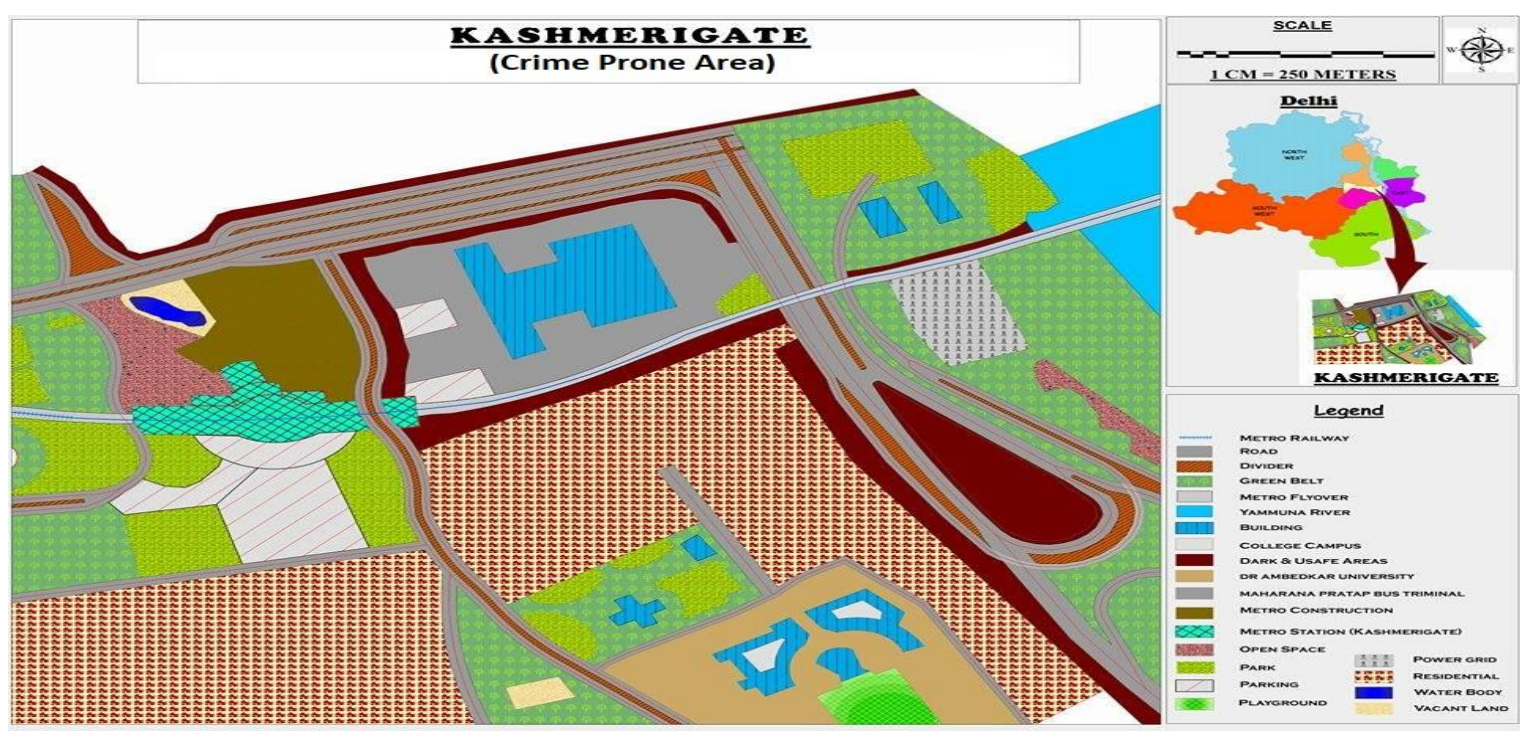

Figure 08: Kashmiri Gate-ISBT (Sources: Google Earth, 2018 and GPS Survey)

h) Sarai kale Khan ISBT and Nizammuddin Railway Station: In the south-west part of Delhi, Sarai Kalen Kha is another major interstate Bus terminal and close to Major Railway Station-Hazrat Nizzamudin, where mobility of people is always high (figure 9 \&11). Due to high crowded place, it is a haven for criminals, most of the non-heinous crime like pick pocketing, assault, abuse and snatching occurred here. The offenders live in Mayur Vihar, Ishaq Basti, Neela Gumbad, Beholpur, Noida, Nizamuddin and Ganga Vihar (table-1). The entrance areas of the station are very crowded without proper monitoring by the traffic police. There are bushy and dark places behind the industrial site, which need to be pruned so that the area can be lighted up and the visibility can be maintained. CCTV cameras should be installed. The belt along the Yamuna River is highly crime prone and the road leading to Nizamuddin Railway Station from ring road is prone to snatch and pick-pocketing. CCTV 
cameras should be monitored properly crowded streets. Parks and streets should use surveillance devices to prevent crime (figure 9).

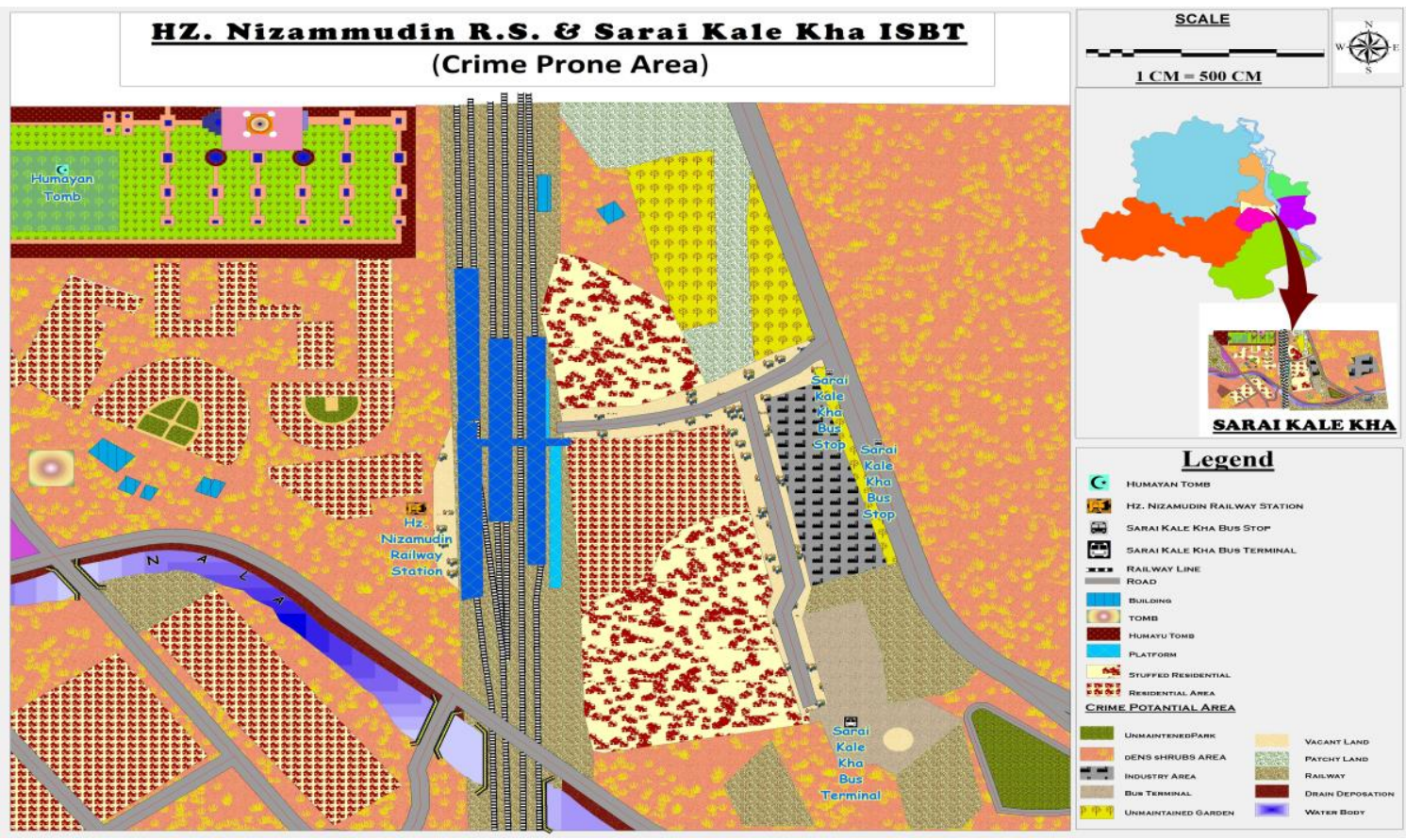

Figure 09: Nizammuddin Railway Station (Sources: Google Earth, 2018 and GPS Survey)

i) Vasant Kunj (Nelson Shopping Center) Bus Stand: In the southern part of Delhi, one of the prominent places in Vasant Kunj, where assault, abuse, molestation, snatching and pick pocketing are usual incidence (figure 10 \&11). Most of the offender lived in Kapashera Border, Mahipalpur Village, Rangpuri Pahari and Munirka Village (table-1). This place has wide, un-landscaped patches along the roads without surveillance devices and proper light at night. The divider is wide and rough. At night the entire area gives a deserted look which is favourable for criminals to commit crimes. Within $500 \mathrm{~m}$ from this place, there are open wide areas with bushes and tree without fencing and surveillance device. Therefore, there is a need for proper fencing, the arrangement of lights, pruning of trees and bushes to enhance visibility and landscaping of patches along both sides of the road. This will prevent criminals from committing crimes and will remove fear from the mind of the public (figure 10).

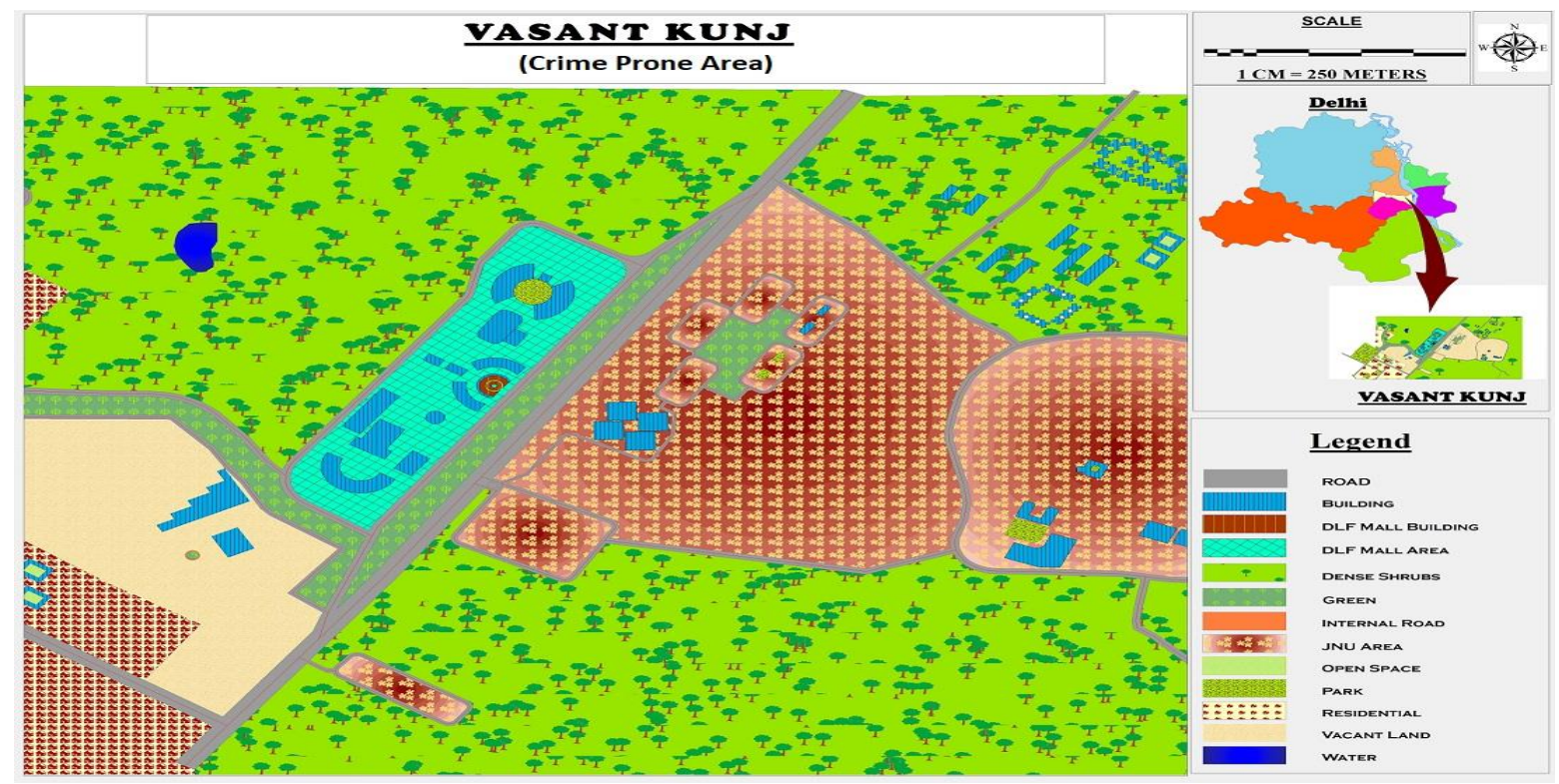

Figure 10: Vasant Kunj (Sources: Google Earth, 2018 and GPS Survey) 
j) Old Delhi Railway Station: As we found, the offender easily targeted the railway station and bus terminal as well as Old Delhi Railway station, are the major hotspots for offenders because of the crowd and high mobility of people (figure 11). Crimes such as pick pocketing, snatching occurred here. Other crimes like motor vehicle theft are also common. Most of the offenders lived in Kodia Pul, Seemapuri, Narela, Pulbangash, Sadar Bazaar, Yamuna Bazar, Chandni Chowk, Fatehpuri, and Seelampur area (table-1). This is a very busy hotspot place and people from diverse socio-economic background arrive here. Presence of tea corner near parking, the crowd outside the station and area near foot-over Bridge is being crime prone in the night. Although railway platform is well under surveillance, however areas along rail tracks need proper maintenance, fencing and installation of digital devices.

Anand Vihar stands first among all the above crime hotspots and it could be due to the tri-junction of railway-metro and buses terminal. Due to tri-junction the area known as the high mobility of people, the floating population from the different direction and vacant plots/ isolated places, bushy areas nearby the hotspot and being next to the Uttar Pradesh border are the features, which make it crime-prone and hotspot of this region. We also observed that less of surveillance and patrolling of cops to be the reason for the high level of crime.

This is observed that pick-pocketing, snatching, assault and abuse are the frequent incidences which are recorded at a higher rate in these places, whereas the hotspot like Old Delhi and Nizamuddin recorded less crime compared to other places. The reason for less crime was because of well-illuminated roads, public awareness, electronic surveillance and lack of vacant place and dark spaces, well-maintained parks and less blind corners. Rape, murder, robbery and burglary were recorded lowest among all the crime cutting across all the hotspot places. The reason for this could be that there is no simple way of escaping because of the crowded area. Through the above discussion, we can say that with the modification of the built environment can reduce the opportunity of crime and to promote community responsibility (Gupta, 2020a). The planning and design of a place play an important role in choosing a place to commit a crime by the offender.

It is observed that the major crime-prone area in perused then in north-east: Seemapuri, Usmanpur, Mustafabad, New Usmanpur, Kalyanpuri, in western part; Najafgarh, Dabri, southern Vasant Vihar, Najafgarh and northern part Jahangirpuri, Bhalswa Dairy, Wazirpur, etc. comes out as prominent (table-1). It is seen that the areas lying on the borders are most prone to crime. These are places where criminals from Uttar Pradesh and Haryana find a haven. It is easy to move from Anand Vihar, Kalyanpuri to Noida and Ghaziabad and from Jahangirpuri, Sultanpuri to Jhajjar or Sonepat. It is found that there are no changes in the ascription of offenders during two time periods. Table 1 shows the detail ascription of criminal in relation to crime hotspots of the city.

These are the crime like pick pocketing (17 percent) followed by snatching (13 percent), assault (17 percent), while burglary is the lowest $(0.14$ percent) were very familiar in most of the crime hotspots (figure 12). The spatial pattern of crimes at hotspot places, like pick pocketing ( 27 percent) has been reported highest followed by snatching ( 26 percent) at Seemapuri Bus terminal, whereas snatching is lowest at Vishwavidyalaya Metro Station and New Delhi Railway Station (12 percent each). Among all, the highest incidence of molestation was recorded at Vishwavidyalaya Metro Station (21 percent) followed by Vasant Kunj (NSC) Bus Stand, both come under posh areas. 


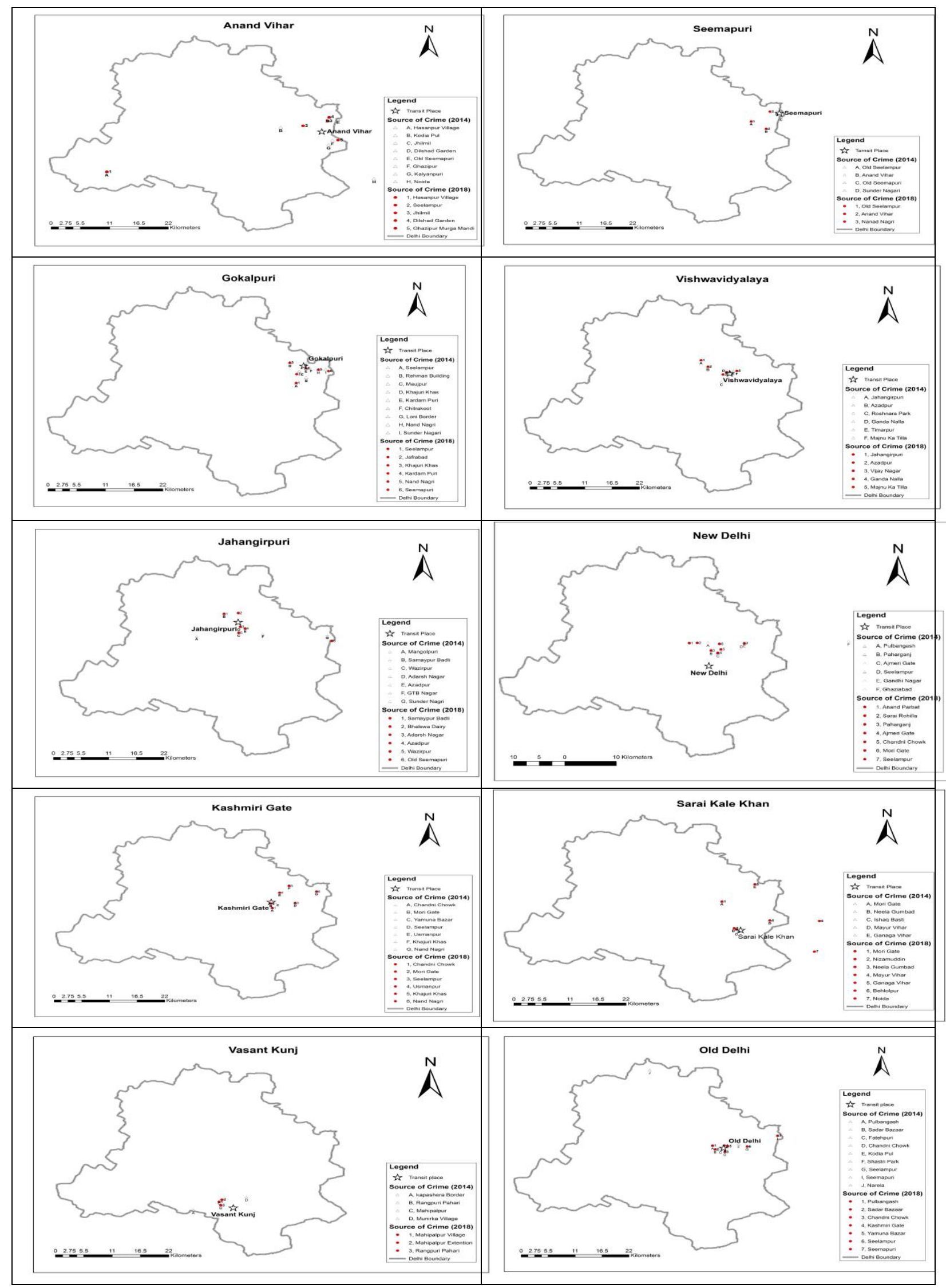

Figure 11: Major Hot Spots of Crime 
The overall study shows that Bus Stand was most vulnerable to crime ( 25 percent) as they are neither patrolling by police nor well-maintained surveillance devices. Next is to Railway Station (21 percent), followed by bus terminal-ISBT (16 percent) because it is under surveillance by the terminal authorities and covered by boundary walls, whereas the metro station ( 7 percent) had less crime due to proper special security personal and monitor through digital Surveillance devices (figure 13).

Table 01: Ascription of Criminals in Hotspots

\begin{tabular}{|c|c|c|c|}
\hline \multirow[t]{2}{*}{ Hotspots } & \multicolumn{3}{|c|}{ Distance between offenders Residence to Crime hotspot (in $\mathrm{Km}$.) } \\
\hline & $\begin{array}{c}\text { Source Areas } \\
\text { (Common in both years) }\end{array}$ & $\begin{array}{l}\text { Newly Emerging } \\
\text { Areas in } 2018\end{array}$ & $\begin{array}{c}\text { Area which are No } \\
\text { more }\end{array}$ \\
\hline $\begin{array}{l}\text { Anand Vihar } \\
\text { Bus/Metro \& Rail } \\
\text { Terminal }\end{array}$ & $\begin{array}{l}\text { Jhilmil (4.2), Ghazipur (2.97), Hasanpur } \\
\text { Village (3.2), Old Seemapuri (4.32), } \\
\text { Dilshad Garden (4.98) }\end{array}$ & & $\begin{array}{l}\text { Kodia Pul (13.4), Noida } \\
\text { (15.37), Kalyanpuri } \\
\text { (5.75) }\end{array}$ \\
\hline $\begin{array}{l}\text { Seemapuri Bus } \\
\text { Depot }\end{array}$ & $\begin{array}{l}\text { Anand Vihar (6.10), Old Seelampur } \\
(6.64)\end{array}$ & Nand Nagri (3.9) & $\begin{array}{l}\text { Sunder Nagari (1.93), } \\
\text { Old Seemapuri (0.75) }\end{array}$ \\
\hline Gokalpuri Bus Stand & $\begin{array}{l}\text { Seelampur (4.54), Nand Nagri (3.4), } \\
\text { Khajuri Khas (4.42), Kardam Puri (0.86) }\end{array}$ & $\begin{array}{l}\text { Jafrabad (3.7), } \\
\text { Seemapuri (6.3) }\end{array}$ & $\begin{array}{l}\text { Loni Border (2.5), } \\
\text { Maujpur (2.1), Rehman } \\
\text { Building (3.04), } \\
\text { Chitrakoot (1.8) }\end{array}$ \\
\hline $\begin{array}{l}\text { Vishwavidyalaya } \\
\text { Metro Terminal }\end{array}$ & $\begin{array}{l}\text { Majnu Ka Tilla (1.21), Ganda Nalla } \\
(0.60), \text { Azadpur (4.8), Jahangirpuri (7.13) }\end{array}$ & Vijay Nagar (1.8) & $\begin{array}{l}\text { Roshnara Park (3.72), } \\
\text { Timarpur(1.3km) }\end{array}$ \\
\hline $\begin{array}{l}\text { Jahangirpuri Metro } \\
\text { Terminal }\end{array}$ & $\begin{array}{l}\text { Samaypur Badli (6.5), Adarsh Nagar } \\
\text { (2.31), Wazirpur (4.9), Azadpur (2.10) }\end{array}$ & $\begin{array}{l}\text { Bhalswa Dairy } \\
\text { (2.9), Old } \\
\text { Seemapuri (22.7) }\end{array}$ & $\begin{array}{l}\text { GTB Nagar (6.32), } \\
\text { Mangolpuri (10.7), } \\
\text { Sunder Nagri (18.8) }\end{array}$ \\
\hline $\begin{array}{l}\text { Old Delhi Railway } \\
\text { Terminal }\end{array}$ & $\begin{array}{l}\text { Chandni Chowk (3.0), Seemapuri (11.5), } \\
\text { Pulbangash (4.2), Sadar Bazaar (5.5), } \\
\text { Seelampuri (6.6) }\end{array}$ & $\begin{array}{l}\text { Kashmiri Gate } \\
(2.1), \text { Yamuna } \\
\text { Bazar (1.8) }\end{array}$ & $\begin{array}{l}\text { Kodia Pul (2.1), } \\
\text { Fatehpuri (1.79), } \\
\text { Shastri Park (5), Narela } \\
(33.3)\end{array}$ \\
\hline $\begin{array}{l}\text { New Delhi Railway } \\
\text { Terminal }\end{array}$ & $\begin{array}{l}\text { Ajmeri Gate (0.8), Seelampur (11.00), } \\
\text { Paharganj (1.00) }\end{array}$ & $\begin{array}{l}\text { Anand Parbat } \\
\text { (5.5), Sarai Rohilla } \\
\text { (6.3), Chandni } \\
\text { Chowk (2.7), Mori } \\
\text { Gate (5.6) }\end{array}$ & $\begin{array}{l}\text { Ghaziabad (32.2), } \\
\text { Pulbangash (4.52), } \\
\text { Gandhi Nagar (9.6) }\end{array}$ \\
\hline Kashmere Gate ISBT & $\begin{array}{l}\text { Khajuri Khas (8.4), Usmanpur (6.5), } \\
\text { Nand Nagri (11.7), Chandni Chowk } \\
\text { (2.88), Mori Gate (0.95), Seelampur (6.2) }\end{array}$ & & Yamuna Bazar (3.5) \\
\hline $\begin{array}{l}\text { Sarai Kale Khan Bus } \\
\text { \& Nizammuddin } \\
\text { railway Terminal }\end{array}$ & $\begin{array}{l}\text { Neela Gumbad (2.3), Ganaga Vihar } \\
\text { (1.7), Mayur Vihar (7.9), Mori Gate } \\
\text { (12.65), }\end{array}$ & $\begin{array}{l}\text { Beholpur (1.3), } \\
\text { Noida (17.8km), } \\
\text { Nazimuddin (2.8) }\end{array}$ & Ishaq Basti (0.45) \\
\hline $\begin{array}{l}\text { Vasant Kunj (Nelson } \\
\text { Shopping Center) } \\
\text { Bus Stand }\end{array}$ & Rangpuri Pahari (2.9) & $\begin{array}{l}\text { Mahipalpur Village } \\
\text { (4.5), Mahipalpur } \\
\text { Extn. (4.5) }\end{array}$ & $\begin{array}{l}\text { Kapashera Border } \\
\text { (11.1), Mahipalpur } \\
\text { (4.1), Munirka Village } \\
\text { (3.64) }\end{array}$ \\
\hline
\end{tabular}

Source: Primary Survey, 2014 and 2018

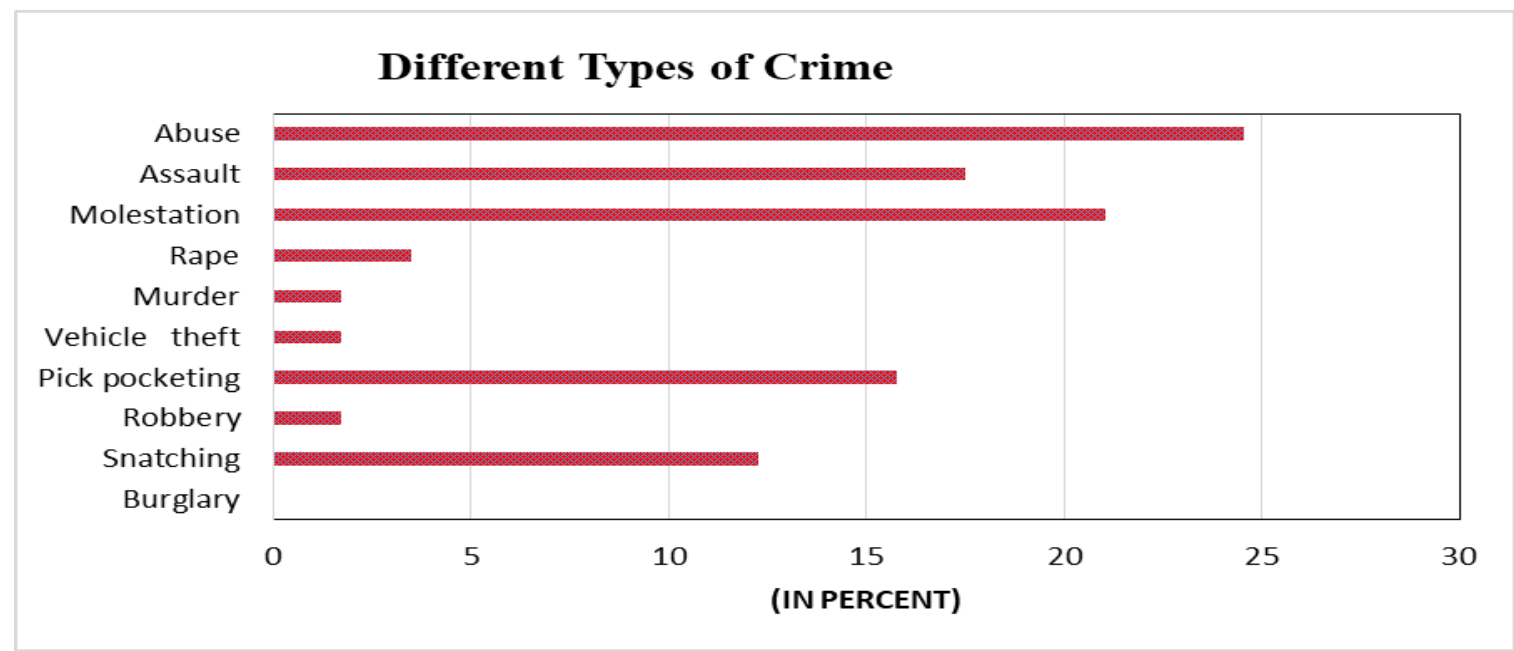

Figure 12: Perception of Crime at hotspots (Source: Primary Survey, 2014 and 2018) 


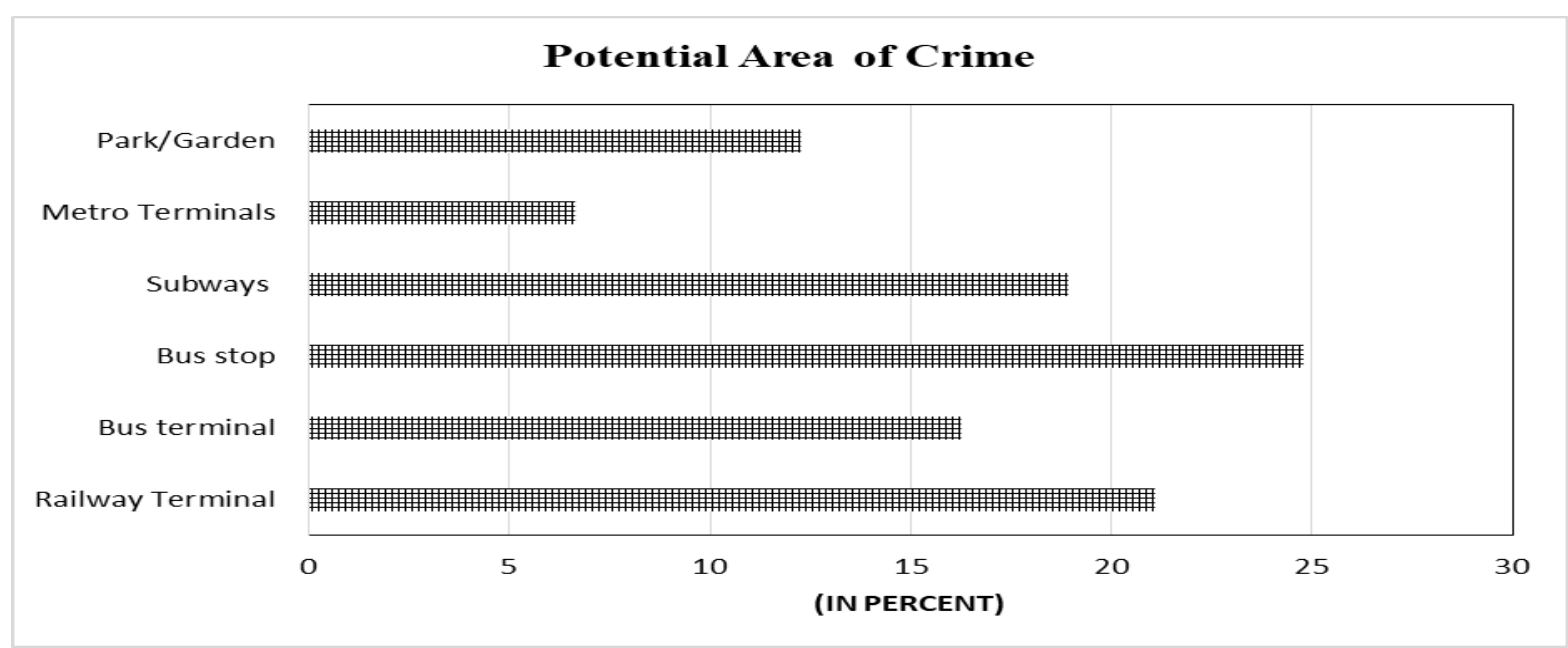

Figure 13: Major Crime Prone Places (in percent) (Source: Primary Survey, 2014 and 2018)

Figure 14 reveals that most of the crime (24.72 percent) occurred in 100 to 500 meters from the railway/bus/metro station. The 22.88 percent crime occurred in $50-100$ meter, and very less crime occurred inside the bus stand, railway station and metro station. The figure shows that maximum (83 percent) crimes occurred within 500 meters from the major hotspots after that crime decreased.

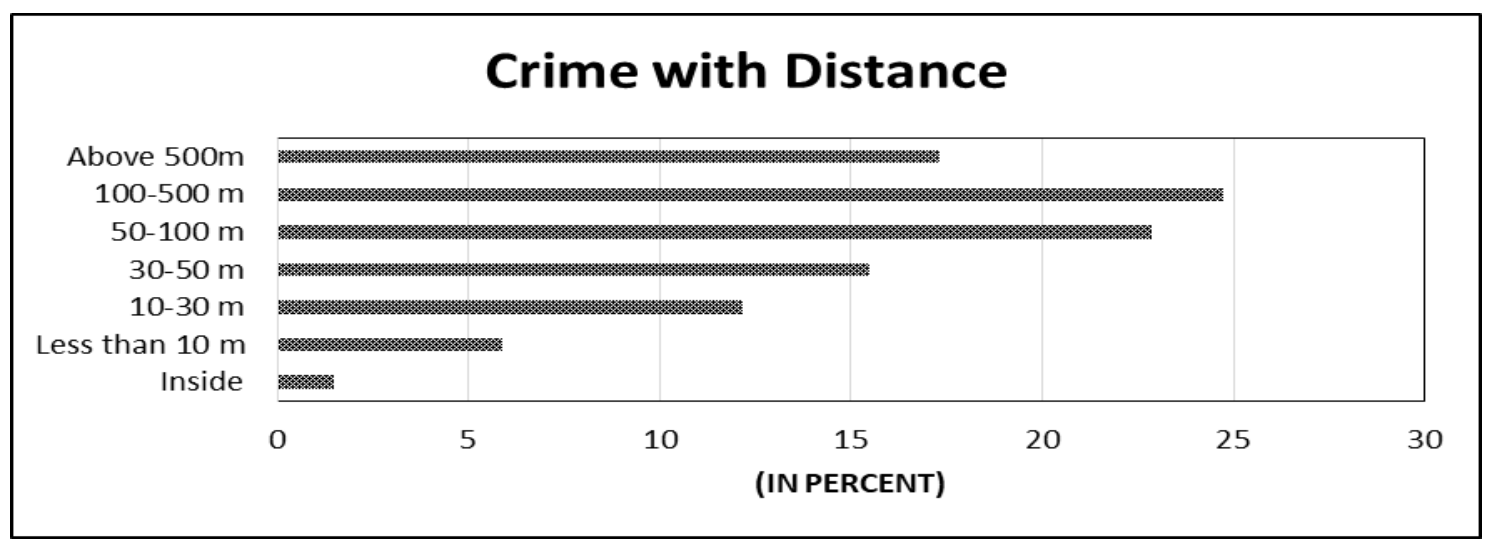

Figure 14: Distance and Crime (in percent) (Source: Primary Survey, 2014 and 2018)

\section{Conclusion}

This paper presents a spatial pattern of crime and describes the areas with a significantly high frequency of crime due to poor layout design of buildings. This is observed that there were no major changes in criminal ascription between five years. Brantingham and Brantingham, 1995; discussed that the crime occurs when there is a motivated offender, a suitable target and lack of prevention; converging at the same place in same time. This paper brings out that poor infrastructure, faulty design and building layout, inadequate protection and lack of surveillance provide opportunity to the offender. When the infrastructure is improved, it reduces the opportunity for crime which was when metro station, fencing of drains and lighting came up in areas such as Sarai Kale Khan/Nizamuddin, Gokalpuri (Gupta,2020a). Validating the Routine Activity Theory, the findings of this paper also show that most of the time the criminals travelled shorter distances that is $4 \mathrm{kms}$ to commit crime. Remedial actions to reduce a feeling of insecurity should be directed, in the first phase, at aspects of urban design, by introducing urban facilities that would encourage the development of a natural vigilance system, ensuring that buildings and public areas are wellkept and clean, eliminating vestiges of vandalism and graffiti, and providing adequate nighttime lighting. A natural system of vigilance should also be implemented by residents within 
their own homes/institutions/establishments through an alteration in attitudes and behavior. They should be more integrated into the community and encouraged to use shop windows, doors and windows that enable visual contact with the outside. We might expect this combination of factors to lead to better levels of security, with the consequent reduction of feelings of insecurity. However, these measures are by no means a panacea that will solve the crime problem once and for all; policies of micro planning and inclusion should also be implemented alongside these, in order for positive effects to be seen in crime prevention. Coordination between people, neighbours, and society, as well as police patrolling, should be encouraged as short-term measure. A long-term strategy for reducing such crimes is to implement smart city measures, which will make the city less vulnerable to crime.

\section{References}

1. Brantingham, P. L. and Brantingham, P. J. (eds) (1981). Environmental Criminology, Beverly Hills, Sage Publications

2. Brantingham, Paul J. (2016). Crime diversity. Criminology 54.4: 553-586.

3. Brantingham, P. and Brantingham, P. (1995). 'Criminality of place', European Journal on Criminal Policy and Research, 3(3), 5-26.

4. Census of India (2011). Directorate of Census operations Delhi. Provisional Population Totals, Paper 1 of 2011, NCT of Delhi, Directorate of Census operations, Delhi. Census of India, $(2001,2014,2018)$ Statistical Abstract of Delhi-2014, (http://www.censusindia.gov.in/2011common/census_data_2001.html)

5. Clark, William L. and Marshall, William L. (1952). A Treatise on the Law of Crimes (5th ed. Chicago: Callaghan).

6. Crowe, Timothy. (2000). Crime prevention through environmental design, pub. ButterworthHeinemann.

7. Delhi Police (2020, 2010). Delhi Police Crime Statistics 2001-2010. and Delhi Police Crime Statistics 2011-2020. http://delhipolice.nic.in/PDF/CID.pdf, different crime heads.

8. Duzgun, S. (2007), "Suç Olgusuna Teorik Yaklaşımlar ve Disiplinlerarasılık", Dosya 6, TMMOB Mimarlar Odası Ankara Şubesi, bülten 55/ Kasım- Aralık, p.4-10

9. Erdogan, Aygün. (2007). Exploring Crime in a Spatial and Temporal Context: Suitable Response Strategies for Urban Planning and Policing By the Case of Etlik Police Station Zone. Ankara: Orta Doğu Teknik Üniversitesi Fen Bil. Ens. Doktora Tezi

10. Geason, S. \& Wilson, P. 1989 - Designing out Crime: Crime prevention trough environmental

11. design, Australian Institute of Criminology, Renwick pride Pty Ida, Albury, Australia.

12. Goldsmith, V. \& McGuire, P. (2000). - Analysing Crime Patterns: Frontiers of Practice, Sage

13. Publications, USA.

14. Government of India Compendium. (2011). Crime in India, National Crime Records Bureau, Ministry of Home affairs, www.ncrb.nic.in

15. Gupta, R. (2020a). Behavioural Mapping of Crime Hotspots in Delhi: A Spatial Analysis, Transaction-Journal of the Institute of Indian Geographers, Vol.42, No.2, pp 283-297.

16. Gupta, R. (2020b). Urbanization and Urban Crime in India: a case study, Urban India, Volume 40, No.2, pp 138-160, July-Dec. 2020.

17. NCRB, (2011). GOl's compendium "Crime in India" National Crime Records Bureau, Ministry of Home affairs.

18. National Crime Records Bureau-NCRB $(2011,2018,2019)$. Ministry of Home affairs, Govt. of India, www.ncrb.nic.in

19. Newman, O. (1972). Defensible Space, Macmillan, New York, NY.

20. Ratcliffe JH (2009). The structure of strategic thinking. In: Ratcliffe JH (ed) Strategic thinking in criminal intelligence, 2nd edn. Federation Press, Sydney

21. Rosiers, N.D.; Bittle, S. (2004). What is a Crime? Defining Criminal Conduct in Contemporary Society, UTP Distribution, Toronto, Ontario

22. Tappan, P., Crime. (1960). justice and correction, New york: McGraw Hill book co.

23. Tobler W (1970). A computer movie simulating urban growth in the Detroit region. In: Economic geography, 46(Supplement: Proceedings. International Geographical Union. commission on quantitative methods. (June, 1970)) pp 234-240 